\title{
Rethinking Class in Lesbian Bar Culture Living 'The Gay Life' in Toronto, 1955-1965
}

\section{Elise Chenier}

When Joji Hazel came to Toronto in the early 1960s, her search for a gay women's bar landed her at the Continental Hotel, a public house long considered home to local bar-going lesbians. ${ }^{1}$ Hazel lived in a small town one hundred miles outside the city, and what she knew of lesbian bars was gleaned from pulp fiction novels and The Ladder, a magazine published by the Daughters of Bilitis, a San Francisco-based lesbian organization, where the evils and merits of lesbian bars and butch and fem 'roles' were the subject of regular debate. ${ }^{2}$ Hazel claims that she felt well prepared for what she would find, but as she stood before the "dingy building" located in "a seedy section of Chinatown, noted for prostitution and narcotics," she almost lost her nerve.

Had Hazel never read about lesbian bars, she probably would have been struck by the tough masculine demeanour of many of the women inside. She might have been put off by the constant stream of sex trade workers and johns moving in and out of the ladies' and escorts' room. But after three hours of careful observation, what took her by surprise was how the gay women inside were segregated into two distinct groups. They are "stalwarts from two different worlds," she explained in a short article published in The Ladder in 1963. "One ... was condescending and at times a little jeering; the other was brash, defiant, puzzlingly defensive .... A line might have been drawn on the floor, so divisible were the players." ${ }^{3}$ Significantly, Hazel knew exactly where she stood, or more precisely, sat. Her description of "brash" butches at the Continental was unequivocally critical; presumably why some women might jeer at them needed no explanation.

Butch and fem "roles" have long been regarded as a definitive feature of post-World War II working-class lesbian culture, but as Hazel discovered, sociability within Toronto's lesbian subculture was tied to a much more complex set of friendship networks that divided women as much as they united them. ${ }^{4}$ In Toronto, women whose lives centred on the Continental Hotel called themselves downtowners, and referred to other gay women in the bar - women like Hazel - as uptowners. Uptowners typically lived outside the downtown core, usually in the rapidly expanding suburbs. Some still lived at home, others with friends and lovers. Most held down pink and, to a lesser extent, whitecollar jobs, and were careful to separate their "gay lives" from their familial and working lives. Limiting their time in the Continental and the surrounding 
neighbourhood to weekends has been described as an important strategy to minimize the perceived risk of being discovered in a "homosexual haunt," but it also reflected typical patterns of socializing among the gay urban employed. Lesbians and gay men referred to the process of separating, negotiating, and living out two distinct lives as "the double life."

In contrast, downtowners lived "the gay life." They were a constant presence in the back room of the Continental Hotel's public house, and their daily activities were deeply enmeshed with most every aspect of the social and economic activities of the beer parlour and its surrounding neighbourhood. From the early 1950s until the mid-1960s, to live the 'gay life' was to live in tandem and in tension with the sex and drug trades, local Chinese residents, the police, the courts, and the prison system. Those who did so gave clear expression to their particular location within the community through their rough and ready style. Butch and fem downtowners were identifiable to insiders and outsiders alike: more assertive in staking their claim on physical and social spaces, more willing to challenge conventions concerning sex and gender comportment, and more sexually explicit in their verbal and physical interactions, they comprised a distinct social group of sexual outsiders. Of course, the line that divided the two groups was not immutable. Most downtowners arrived as uptowners, and some women dated and socialized across the "line." However, as "kiki" was to butch and fem, lesbians who sought out and enjoyed the friendship and trust of both groups were the exception to the rule. ${ }^{8}$ For the purposes of this article, downtowners can be distinguished as a unique and relatively stable social category.

Similar class distinctions among bar-going lesbians were made in other Canadian and American cities as well. Elizabeth Lapovsky Kennedy and Madeline D. Davis's comprehensive study of the Buffalo lesbian community argues that in the 1950s and 60s "rough and tough" lesbians, known as the "riff raff," were set apart from the "elite lezzies." In Stone Butch Blues Leslie Feinberg's semi-autobiographic novel set in the same period, the protagonist strongly identifies with Buffalo's regular bar crowd and derisively refers to masculine women who come to the bar only occasionally as "Saturday-night butches."10 In 1950s Denver, Colorado, women who referred to themselves as the "Blue Jeans" called "upwardly mobile" lesbians "Blue Bloods."11 One woman described those who frequented The Lighthouse in Lynn, Massachusetts as "the working class and the not-working class." 12 Where there were enough gay women to sustain them, the two groups tended to self-segregate in separate bars. ${ }^{13}$ Until the early 1960s, however, in Toronto the Continental was considered the only thing going.

By focussing on "the gay life" in post-World War Two Toronto, this essay seeks to extend existing ideas about class in the historiography of Canadian and 
American lesbian bar cultures. To date, virtually all studies of lesbian bar culture in this period rely on categories of class to describe and account for the emergence and proliferation of bars and other commercial spaces where butch and fem women constituted a regular and visible presence. While many of the women who appropriated bar space were working class and the bars they frequented tended to be in working-class neighbourhoods, the implications of class identity and culture for an emerging sexual subculture during a time of considerable political repression is often under-theorized. It is sometimes assumed, for example, that working class women were more willing to risk being publicly identified as a homosexual because they had "less to lose" than their middle class counterparts. ${ }^{14}$ Unfortunately, this undervalues the significance of what working class and underemployed women had, and what they needed to survive. It also detracts from a full consideration of the meaning and the impact of the choices they made.

Kennedy and Davis provide the most sustained analysis of class for this period. Their meticulous investigation of the growth and evolution of Buffalo's lesbian bar culture from the 1930s to the 1960 s offers crucial insights about class differences among gay women, and illustrates how butch and fem culture drew on the more general working-class cultures in which they were located. However, "working-class" as a category of analysis is sometimes applied in a very general and even essentialist fashion. For example, they observe the 1950s emergence of "rough bar lesbians" within the existing Buffalo bar scene. Distinct from "upwardly mobile" lesbians, they argue that tough bar lesbians" willingness to defend themselves physically is "a trait associated with workingclass culture in general."15 They continue, "Only working-class women had the tradition of strength and ability to defend themselves in extremely difficult and violent conditions." Kennedy and Davis also describe these women's desires to be "more physical and more explicitly sexual when socializing" as "characteristics associated with the working class."16 Yet research into Toronto's bar culture shows that the tough bar lesbian did not just draw on a wider working-class tradition. As a class, they emerged out of a very particular set of circumstances in which they lived, socialized, and supported themselves (and sometimes their partners and children).

In this essay I show that the working class character of Toronto's tough bar lesbians derived not simply from the rough and tumble nature of working-class culture but from the concrete survival strategies lesbians carved out from the street and underground economy, strategies that were shared by a number of different marginalized groups, including prostitutes. Like other gay women, downtowners' identities took shape in the context of homosexual repression and considerable sexual, social, and economic restraint imposed on women. What distinguished downtowners from other working class gay women, however, was the result of their direct and indirect involvement in a variety of crim- 
inalized socio-economic activities, all of which occurred in and around the public spaces they themselves secured. Downtowners' economic relationships were also social relationships, and they shaped female sexual subjectivity in ways that cannot be explained by lesbian identity or class difference. Instead, I argue that class and sexuality were mutually constitutive. ${ }^{17}$ By examining the social and economic consequences of living "the gay life" full time, we can begin to think more carefully about how we use "working class" as an explanatory tool in the shaping of sexual cultures and gender identities.

This article is part of a larger study of lesbian bar culture in post-war Toronto that I began in the early 1990s. Primary source material includes interviews conducted in the mid-1980s by the Lesbians Making History collective; in 1992 and 1993 I added seven interviews of my own. These are supplemented with gossip columns and news stories in Toronto's weekly tabloids Justice Weekly, Confidential Flash, and Hush Free Press where local lesbian's engagements with the police and the courts were occasionally covered, and by the records of the Liquor Licensing Board of Ontario. No sources provide us with a transparent view of the past, and oral histories and the yellow press come with their own peculiar limitations. ${ }^{18}$ However, historians of queer cultures have skilfully demonstrated that when approached with an eye and ear sensitive to language and narrative these rich resources can be mined to great effect, and offer critical insights into class, culture, and processes of identity formation.

In his 1983 study of American homosexual communities, John D'Emilio argues that World War Two was a turning point in lesbian and gay history. Wartime mobilization disrupted traditional family and community relationships, placing millions of women and men in homosocial environments that contributed to same-sex sexual exploration and discovery. After the Allied victory, large numbers of women and men mobilized by the war effort stayed on in America's port cities and urban centres, where they formed visible public communities in bars and other commercial social spaces. ${ }^{19}$ Subsequent studies, including Kennedy and Davis's massive ethnography of Buffalo's lesbian bar cultures, support his thesis. ${ }^{20}$ In Buffalo, the demand for female labour in wartime had a number of important effects. It drew thousands of rural and semi-rural women into the city from the surrounding region, and higher than usual wages provided women unprecedented social independence and freedom. ${ }^{21}$ As a result, female use of public space expanded. Whether singly or in groups, women seen on city streets, and in movie theatres, restaurants, and bars were less likely to be regarded as of questionable moral character. More and more working-class women could seriously entertain the idea of refusing marriage and, though they would likely experience social disapproval, could reasonably expect to find work and live a modest, but fully independent adult life. Commenting on these trends in a 1947 American publication for lesbian read- 
ers, "Lisa Ben" optimistically declared, "never before have circumstances and conditions been so suitable for those of lesbian tendencies." 22

Despite similar preconditions, the emergence of a postwar lesbian bar culture in Toronto did not follow the same trajectory. Paralleling the wartime developments described by Kennedy and Davis, women from all over Ontario flocked to Toronto, the centre of Canadian wartime production where the demand for female labour was high and paycheques were handsome. Inglis, a Toronto-based manufacturer of appliances converted to wartime production, and by 1944 employed over nine thousand female workers, making it Canada's largest private employer of women. ${ }^{23}$ One of those women was Margaret, a middle-class Anglo-Ontarian who met her life partner at the plant. Bud was the plant's callisthenics instructor, and she and Margaret pursued a sexually intimate relationship that evolved into a celibate, life-long domestic partnership. ${ }^{24}$ According to Margaret, for decades neither she nor Bud understood herself as homosexual, lesbian, or queer. Until the 1990s they remained unaware of any public or private lesbian or gay social networks despite the fact that they lived together for most of their adult lives and Margaret worked in a variety of professional and journalistic positions at the Canadian Broadcasting Corporation which was known for its homosexual cliques. ${ }^{25}$

Margaret and Bud's experience illustrates the great care with which many lesbians and gay men guarded their homosocial interests and homosexual relationships. Still, other lesbians and gay men were able to use public spaces to make themselves more visible, and provide opportunities to socialize with one another. During and after the war, gay women established a discrete but discernable presence on the Inglis and other organized women's softball teams, and some participated in the predominantly gay male social activities, including dances, sunbathing, and private parties on Toronto's Ward and Centre Islands. ${ }^{26}$ The Wheat Sheaf, a private, unlicensed dance club located at Yonge and College Streets, was frequented by gay men and women and survived into the 1950s. ${ }^{27}$ Details about its opening and closing dates, its ownership and management, and even the clientele are yet to be documented, but it is quite likely that the economic and social opportunities provided by the war enabled its existence.

However, for many women the ideal conditions "Lisa Ben" described in 1947 were quickly eroding. Toronto's industrial economy peaked with 160,000 labourers in 1950, but over the next decade, factory jobs dried up as heavy industry moved their operations out of the downtown core. ${ }^{28}$ Female workers maintained a strong presence in small manufacturing outfits that clung to the city's economy, but inside the few large-scale operations that remained men were once again the preferred employees. By 1961, for example, only fifty women were employed at Inglis' downtown factory. Moreover, wartime labour gains were unevenly distributed. For example, few Asian Canadian women 
were able to break into the mainstream labour market, and African Canadian women were quickly pushed off the shop floor and into the service sector at war's end. ${ }^{29}$

Economic change was accompanied by seismic shifts in popular culture, particularly with respect to expectations about female behaviour. ${ }^{30}$ Plentiful opportunities in retail, restaurant, and administrative sectors meant that single Toronto women would have little trouble finding work, but each of these types of positions demanded feminine deportment. Butch women determined to live the gay life full time were less able to access these jobs. In 1950s and 60s Toronto, butch lesbians found employment driving cabs, and a small group of gay women held down jobs as pieceworkers at McFarlane-Gendron, a Toronto manufacturer of baby carriages. ${ }^{31} \mathrm{~A}$ few trained as auto mechanics (the 1961 census reports a total of fourteen female mechanics in the city); some picked up work in local car washes, or as bowling pin setters, handbill distributors, or couriers; and by the late 1960s Tilden, Avis, and other car rental companies employed a sizable contingent of butch lesbians as car jockeys. ${ }^{32}$ Overall, however, employment options for young masculine women were becoming increasingly scarce. When women landed jobs that allowed them to wear pants, shirts, and hair fashioned after contemporary icons of youthful masculinity, they hung onto them as long as they could. ${ }^{33}$ Job vacancies were quickly filled by word-of-mouth. ${ }^{34}$ According to Arlene, it was not that butch downtowners refused to work in traditional female sectors, only that they refused to style themselves according to contemporary female fashions. When they applied for work, they were usually turned away at the door. "[A] person could be hiring one hundred people and [a butch] walk[s] in and: 'Sorry, we're not hiring.' Which is why a lot of criminal activity went on: people had to live, they had to eat." ${ }^{35}$ Despite the greater availability of full time work for young single women, butch lesbians who chose to live the gay life full time found they had depressingly limited options. The street economy provided an alternative that many were willing to take.

A 1966 sociological study of Toronto's female homosexual subculture supports Arlene's claim. Jo Ann Pratt, a master's student in the School of Social Work at the University of Toronto, interviewed thirteen lesbians, most of whom had a criminal record; among the most frequently laid charges were drinking (ten), theft (six), prostitution (five), drugs (five), and robbery with violence (three) ${ }^{36}$ These and other criminal charges were often the result of a combination of poverty and what we would now call homophobia. For example, a charge of breaking and entering might be laid against a woman who broke into a car so she could sleep for the night; a charge of disturbing the peace could be laid against two women having a lover's quarrel on the street; and women breached their probation when they refused to stay out of the Tenderloin and 
Chinatown areas. ${ }^{37}$

Of course, Pratt's methodology determined the outcome of her research. She relied on a middle class lesbian to escort her to the Continental and other commercial establishments with a lesbian clientele, but most of the women who filled out her questionnaire were contacted through the Mercer Reformatory, the Don Jail and Probation Services. ${ }^{38}$ Pratt's goal was to understand the lesbian and her relationship to the social world around her, but rather than provide readers with a snapshot of "the lesbian," by relying on the criminal justice system to gain access to informants, her sources offered her a snapshot of the downtowner. Indeed, in the 1950s and 60s prisons, jails, and probation services were a sure bet for finding lesbian subjects. When jobs were impossible to find, or paid too little, or were simply too hard to hang on to, the local sex and drug trade provided a variety of ready economic opportunities that some were willing to exploit. These women's social location within the bar and their allegiances to the women and men in it was largely determined by just that decision.

The cultural changes evinced by women's war work may have helped create the conditions necessary for greater female autonomy, but if a public community accessible to outsiders emerged during the war, gay women in Toronto were unable to sustain it. Instead, the 1950s evolution of Toronto's lesbian bar culture followed pre-war urban patterns when public homosocial cultures emerged in vice districts where female prostitutes were a stable and visible presence. ${ }^{39}$ Sex trade workers were scattered throughout the downtown core, but in the early 1950s Toronto had two particularly well-known red light districts. The "Tenderloin" ran along a section of Jarvis Street near Carleton in Cabbagetown, an east end Anglo-Celtic working-class neighbourhood. The other was to the west, at the corner of Elizabeth and Dundas Streets, the heart of Chinatown. In the first half of the 1950s, gay women were a constant and visible presence in the Tenderloin, but after 1955, Chinatown was widely known as the centre of public lesbian life.

Up until the mid-1950s, lesbians were most likely to be found in public houses along Jarvis Street. The Rideau Hotel was one of the more popular, perhaps because it had one of the few remaining "ladies only" rooms. ${ }^{40} \mathrm{In}$ an effort to prevent sexual immorality (and appease temperance advocates), Ontario liquor licensing laws required that public houses thwart heterosexual contact between strangers by providing at least two physically separate rooms: one for men only, and the other for women. Up until the early 1970s when feminists launched a successful campaign against such forms of segregation, men could gain access to what were called "ladies and escorts rooms" only by entering with a woman. ${ }^{41}$ The Rideau's "women only" room made it particularly well suited to gay women's social needs. Not only did it allow them space to socialize with each other, but it also shielded them from heterosexual advances and 
male antagonism. As Davis and Kennedy have argued, bars frequented by straight men were hostile environments for butch and fem lesbians. The combination of excessive alcohol consumption and the greater tendency for arguments to escalate into physical violence in and around working-class bars meant that the likelihood of assault was much greater in "street bars" than in other, more upscale places. ${ }^{42}$ Indeed, liquor authority complaints regarding drunkenness, rowdiness, and fights among patrons preceded the arrival of gay women. ${ }^{43}$

Given these circumstances, it seems logical to assume that butch and fem lesbians were eager to maintain a distance from heterosexual men. This was not, however, the case among Toronto downtowners. Rather than avoid male patrons, these women worked to take advantage of straight men's heterosexual interests. For example, butches frequently solicited drinks from male patrons, and men often responded positively to their requests. For women with little or no cash, inviting men to buy them drinks meant a cheap night out, even though it also increased opportunities for friction. Such was the case in 1954 when, according to a story in Justice Weekly, a group of five "husky young women" ranging in age from twenty-three to thirty-two sat drinking together at the Westminster Hotel, just down the street from the Rideau. ${ }^{44}$ One of the women asked a lone male patron named Ethier to buy her a drink. When he refused, she called him a pimp. He replied by calling her and her friends "queers." She retaliated by throwing a beer glass at him, and he responded in kind. When Ethier left the hotel a short time later, the women followed him out onto the street. An officer called to the scene reported only that the group was "swearing, shouting and incommoding passersby," but Ethier later testified that the five women threatened to kill him and threw punches and kicked him. All six were charged with causing a disturbance, but charges against Ethier were dropped.

Each of the five women pleaded guilty and was ordered to pay a five-dollar fine or serve five days in prison. Two of the five women were unable to cover the cost of the fine, indicating that the attempt to have their drinks bought for them - public houses were licensed to sell only beer, which then cost ten cents a glass - was born of economic necessity. But the fact that three in the group each had at least five dollars suggests that soliciting drinks from men was an acceptable, not a desperate, practice.

Inviting men to buy you a drink and join your table could also be highly lucrative. Downtowners like Jerry and Joan supported themselves for almost a decade through a variety of illegal activities, but "rolling" men was by far their most profitable. Once seated together at a table inside the bar, one would hold his attention while the other would steal his wallet. The method was not terribly original: pickpocketing was a ubiquitous form of petty theft, and women have long used the sexual interest of men to their advantage. ${ }^{45}$ In the $1950 \mathrm{~s}$, 
pickpocketing was known among its practitioners as "rolling," and local sex trade workers employed similar tactics before, during, or after sexual contact with johns. Downtowners likely learned these skills from them. ${ }^{46}$

Rolling men in bars other than those frequented by gay women would have better enabled women to escape before the theft was discovered and would also have decreased the likelihood of the victim being able to find and identify them. It would have substantially reduced the risk of disrupting other types of activity within the bar and would have made the bar less dangerous for other women. Yet narrators and newspapers reports indicate that theft was common in and around bars popular with gay women. In 1956, four women "in the habit of wearing male attire" reportedly offered a lift to a Japanese man waiting for a streetcar outside the Continental (we might guess that the offer was for something altogether different). He accepted, and they subsequently assaulted him and stole his wallet containing a disappointing $\$ 27$. When the accused appeared in court, "close to a dozen teenaged girls ...wearing male attire and masculine hair-dos" came to cheer the defendants on ${ }^{47}$ Whether or not their friends participated in similar activities is unknown, but those who did clearly enjoyed the support of other downtowners, at least in the face of criminal prosecution.

Inside the bar, women were more likely to befriend a potential victim than assault him, but once theft was discovered, some type of altercation between the victim and his female drinking companions could be expected. However, the danger was greatly minimized by the willingness of other downtowners and the male staff to defend those under attack. ${ }^{48}$ Whenever a male patron threatened a woman, including fems and prostitutes, butch downtowners were expected to rise to her defence. And whenever violent conflict erupted, bar staff were quick to intercede and remove the troublemaker. Oftentimes it was the male victim and not the women who stole from him who was forced to leave. ${ }^{49}$ Bar staff could have discouraged the practice by assisting victims in retrieving their stolen goods and laying formal charges, but according to narrators, theft victims who threatened retaliation were promptly removed from the premises. When women were banned from the bar, it was usually because they became too violent themselves, not because they were stealing from male patrons. ${ }^{50}$

Women who sought out interaction with male patrons were motivated by financial gain, but what inspired men to respond positively to their overtures? Men looking to make a "date" with a sex trade worker needed to gain access to the ladies and escorts room. The requirement that men could enter only with a female patron was not always strictly enforced, particularly in public houses with an active sex trade, but "johns" were often too timid to attempt it, and even less certain about how to proposition a sex trade worker. As a result, butch women often agreed to take men inside in exchange for beer. Lynn, who relied on panhandling for much of her income during the early 1960s, figured "we 
had it made because we could get all these tricks that wanted to go in there because they wanted to be able to sit and get the women that were hooking. So we'd say, 'Okay, you sit with me but you've got to buy my booze for me and my friends." ${ }^{51}$ On a good night, Lynn could treat her mates to an entire evening drinking and socializing without spending any money at all.

Johns were also motivated by sexual interest in butch women. "You'd have a feminine person sitting beside a dyke," Lynn explains, "and the femme going crazy trying to grab a trick and [she's] really pretty and everything, and the guy's looking at the dyke." Lynn thinks that men were attracted to butch women because they believed lesbians hated men, and having sex with one would be an accomplishment of sorts. Kennedy and Davis argue that in Buffalo the majority of bar going women loathed this kind of attention and was one of the principal reasons that upwardly mobile lesbians kept a distance from street bars and the women who patronized them. According to Davis and Kennedy, only a small number of butch lesbians turned tricks in Buffalo. Other women resented the practice because it encouraged johns to proposition other butches.

Hooking among butches was strongly disapproved in Buffalo, but in Toronto, it was common and accepted practice among downtowners. Narrators recall different circumstances under which butches hooked. Since street prostitution was especially fraught with danger, some butch downtowners dating fem prostitutes would rather hook themselves than allow their lovers to go out on the streets. ${ }^{52}$ Lynn recalls butches might hook for their fem lovers when they were not able to work during menses, and Jerry, a butch who had never had sex with men, turned a trick one night when she was stranded in Montreal with no means to return to Toronto. Normally Jerry worked as part of a team with her best friend and roommate Joan. Joan was also butch, and she actively pursued johns in and around the downtown core. Once a date was arranged, Jerry would follow the pair to a hotel or rooming house and enter the room while they were having sex to steal the john's wallet. "To make sure the door wasn't locked, she'd always leave gum [or] ... matches stuck in between the door so it wouldn't lock properly." Jerry and Joan were not the only women to master this method, but no matter how proficient they became it was always an extremely risky venture. ${ }^{53}$ Jerry felt that if they were discovered, she was the one who would either be beat up or turned in to the police, but Joan was persistent and good at talking people into and out of all sorts of things: "She'd pick up these guys and she'd say to me, 'well, we've got one.' [I'd say] 'Oh no, not again.' And like it wouldn't be just one or two guys. Fuck, she'd have two or three a night." When Jerry balked, Joan's charm and persuasiveness usually helped convince her to participate. It also helped get them out of a number of difficult situations. On the few occasions men discovered the theft in progress, Joan was able to convince the male victim not to get angry or lay charges. ${ }^{54}$

For women with no resources, few skills, or little desire or ability to com- 
mit to a regular job, hooking provided fast, but not easy, money. Since gay women congregated in public houses with an established sex trade, the opportunity to turn a trick was always at hand, and if sex trade workers did not actively mentor women, learning how to "crack a trick" (to approach a potential john and negotiate sex for money) could be learned simply by observation. Less obvious was the personal toll it took on women's daily lives. In Pratt's 1966 conversations with gay women about their criminal records, she found that "prostitution evoked more by way of response than any of the other offences." ${ }^{55}$ Women were unanimous in their dislike of the trade, and explained that they did it only for the money. More experienced prostitutes sometimes developed amiable relationships with regular tricks, or "marks," but sex trade work was a source of tremendous emotional and physical stress. Many women used excessive amounts of alcohol or drugs to gird themselves against the danger and discomfort it caused them. ${ }^{56}$

Besides sexually transmitted diseases, one of the trade's major occupational hazards was pregnancy. Narrators claim that butch women were more likely to get pregnant than fems. This suggests that while butch women were known to turn tricks, they did not socialize with fems as sex trade workers, but as friends and lovers, and therefore were less likely to discuss methods of birth control. ${ }^{57}$ However, it also seems likely that the incongruity of pregnant women in full masculine attire left a more lasting impression. Since fem sex trade workers relied on the bar for work and pleasure, those who were pregnant were likely to continue coming to the bar, but straight sex trade workers were less reliant on the bar as a source of social contact. Consequently, any pregnant woman was rather conspicuous. Pregnant butches who continued going to the bar did nothing to alter their appearance, although some wore female clothing to the hospital when they gave birth in order to avoid harassment from nursing and medical staff. ${ }^{58}$ Clearly downtowners accepted both sex trade work and pregnancy as part of the gay life for both butches and fems. Both of these activities set downtowners apart from other gay women who visited the bar.

Further evidence of the important link between the sex trade and Toronto's postwar lesbian bar culture is provided by the mid-decade shift from the Tenderloin to Chinatown as the centre of lesbian public bar culture. In 1949 Montreal's revitalized Morality Squad began a five-year crackdown on gambling and prostitution that culminated in the 1954 electoral victory of Jean Drapeau, an outspoken supporter of anti-vice campaigns, as city mayor ${ }^{59}$ As a result, a significant number of Montreal prostitutes and pimps migrated to Toronto. As the earlier account of the conflict between "five husky women" and Ethier suggests, downtowners took a dim view of pimps and competed with them for the right to use Tenderloin public houses. According to Toronto Police Inspector Jack Webster, many of the Montreal pimps were weightlifters, and there were "some hell of fights" between the two groups. ${ }^{60}$ Tabloid reports 
of "he-shes" getting picked up on the streets reveal that downtown butches were arming themselves with knives and other sharp objects. ${ }^{61}$ They also began staking out a new neighbourhood.

It is not clear why or how women migrated to the Continental Hotel in Chinatown, but conditions there proved particularly favourable to downtowners. Notable for its social and economic isolation from the rest of the city, Toronto's Chinatown provided shelter from the rest of the city's inhabitants. ${ }^{62}$ It also had a well-established sex trade. ${ }^{63}$ Decades of racist immigration laws that at first discouraged the migration of Chinese women and eventually prohibited entry to any person of Chinese origin created what historians have called a married-bachelor society ${ }^{64}$ In the city of Toronto, for example, there were 1758 Chinese men and only 194 Chinese women in $1951 . .^{65}$ The demand for commercial sex continued well into the early 1960s, despite postwar changes to immigration laws.

There was tremendous poverty in the Toronto Chinese community, but there was also a great deal of wealth, and those who had it were willing to pay for more than just sex. Chinese men sought long-term companionship and were not averse to propositioning lesbians. In 1954, Albert Lee approached two gay women in the Nanking Tavern and offered to take them home for drinks. Once there, he proposed to set one of them up "in her own business and buy her a fur coat if she agreed to stay with him." Unfortunately for Lee, she declined his offer and, after he had one too many drinks, his guests left the apartment with some of his personal belongings. ${ }^{66}$ Others proved much more receptive to such arrangements. In 1959, a young Marilyn Johnson left Louis Luke, her much older Chinese lover, for another woman, but when her new lover assaulted her, she promptly returned to Luke. ${ }^{67}$

Where the typical john offered women the possibility of free drinks and a small amount of cash, Chinese men offered women stable housing, spending money, and more. Jerry lived with a Chinese man, but only as his tenant. In 1959 a Hush Free Press reporter claimed, "numerous notorious 'Butch Broads' ... are 'common-law' mates of Chinatown merchants, chefs, etc." ${ }^{\prime 68}$ How many were just renters and how many had more complicated arrangements is impossible to know, but gay women affirm that women and Chinese men formed a variety of personal relationships to one another. ${ }^{69}$ Lois Stewart, for example, was a good friend to a lesbian "nurse and go-go dancer" who wanted children and a secure relationship that presumably she felt unable to find with another woman. The nurse/dancer married a Chinese man who accepted her relationships with other women in exchange for her commitment to their family. ${ }^{70}$

Plenty of Chinese men were charged with running bawdy houses and living off the avails of prostitution, but none apparently were male pimps, or at least not in the Continental. The absence of organized crime and male pimps 
made Chinatown safer for downtowners by reducing the likelihood of conflict with straight men, but it also created opportunities for exploitation. Men with particular sexual interests paid butches to arrange dates with women who met their particular requirements. For example, Jerry was well remunerated by an older white male who was interested exclusively in virgins. ${ }^{71}$ On one occasion, Jerry took advantage of one newcomer's attraction to her by convincing her to have sex with Jerry's contact. She finally acquiesced, though on the condition that Jerry remain in the room with her during the sex act. ${ }^{72}$ According to Jerry, this was not the only date she arranged for this particular john, but it was the only one in which his 'date' was a virgin.

For many (but certainly not all) sex trade workers and downtowners, exploiting johns was fair game, but women who exploited other women were regarded with contempt. Two downtowners in particular were well known for their abusive behaviour that included pimping. ${ }^{73}$ Lynn, a young butch who maintained good relationships with prostitutes, explains that Jan and "Father Murphy" were "rough sons of bitches" who "pretend[ed] they were going with [dating] them and they'd only meet them every day long enough to collect their god damn money. It was nothing for them to grab a woman, throw her up the alley [behind the Continental] and say, 'You're fucking around. You're spending all your money on dope and booze. I need money for my car,' for this and that." 74 They were also known to steal money out of the bras of prostitutes who were either drunk on beer or high on drugs.

Most downtowners rejected this kind of behaviour but were unable to prevent it from happening. Many were terrified to stand up to Jan's clique, who aggressively intimidated other, younger butches and expected other butches to join them. On one occasion Lynn was called upon to participate in the assault of a new young butch, but she refused. "I was sitting and I remember this real cute little dyke came in and they started their shit and one of them grabbed her and threw her on the floor and just like vultures they were there. Mitch turned right around and looked at me and said 'Come on.' I looked right at her and I said, 'You don't fuckin' need me, Mitch, there's four of you on her now. Why the fuck don't you just leave her alone?' I was shocked myself [for having said that] and she looked like she just wanted to grab me and eat me up. But I did$n^{\prime} t$ care anymore, I was fed up seeing it because there was not excuse for it as far as I was concerned." 75 Lynn expected she was next in line for a beating, but instead Mitch bought her a beer the following evening. There was no discussion about what had happened, and while it did not discourage Mitch from meting out the same treatment to other new butches, she never again called on Lynn to join in.

The expectation that butch downtowners be able to fend for themselves may have contributed to their reluctance to intervene in these situations, but this was not the case for fems. ${ }^{76}$ There was no expectation that fems be willing 
and able to fight (though some did), and in fact, butches were expected to shield their fem partners from outside threats. However, as we saw, Jan made no effort to hide her willingness to exploit and steal from fem sex trade workers. Ivy, a fem and sex trade worker who was well respected by many downtowners affirms that "nobody would disapprove of Jan," that the typical reaction was "it's none of our business," and that she was "the only one down there who had any balls to speak up." It's not clear how Ivy communicated her disapproval, but Jan was aware of Ivy's views, and "never took any money off [hookers] if I was there." 77

Individual expressions of disapproval were important, but had only a limited impact. Why didn't more women act to oppose violence and exploitation? Downtowners' positions as sexual outsiders living on the city's economic margins spawned unwritten rules of conduct that militated against collective action directed at other women in the community. All women who went to the bars were expected to keep out of the affairs of others, a fact well understood by downtowners and uptowners alike. Denise, an uptowner who went to the Continental with women she met in her parents' neighbourhood fruit and vegetable store, explains that downtowners "either liked you or they didn't like you," that people were judged on their ability to accept without judgement everyone in the bar, and to take everything and everyone in stride. She thinks she was accepted because "I minded my own business. I was quiet. I didn't cause any problems .... There could be some very bad fights and knives and all that stuff .... I did walk out one night through the back door and there was somebody being pulverized in the parking lot. Well, you just kept going. You didn't interfere. It had nothing to do with you so you made a point of not getting involved." 78 Unless an incident involved you or a close friend, women (and men) were expected to keep their thoughts and hands to themselves.

Downtowners had cause to remain careful about how involved they became with other gay women, including downtowners, and it showed in the various ways they guarded personal information. For example, most women were known to each other only by their nicknames, some adopted an alias, and only a very few revealed their last name to anyone but their closest friends. ${ }^{79}$ The reasons varied: some feared another downtowner might spitefully call their place of work and inform their boss that they were seen at the Continental, a call that would surely result in an immediate dismissal. Others had families actively looking for them, and did not want to be found. But women's participation in criminal activities made minding your own business imperative. Downtowners' involvement with petty theft and the sex trade united them in their vulnerability to police interference and arrest, but maintaining a careful distance from all but one's closest friends was an effective way to guard against the potential threat posed by other women in the bar who could prove unwilling or unable to withhold information from the police. The less others knew 
about you, the less they could reveal. While an effective way to manage the various risks downtowners faced, it undermined their ability to develop stronger and wider friendship networks that would likely have greater success in opposing or preventing violence and abuse within the group.

Added to the mix was the lack of physical, economic, and political resources available to most downtowners. Whereas other Torontonians might call on the police in cases of violent assault, for downtowners this was out of the question (for reasons that will become much clearer below). Additionally, up until the early 1960 s there were few other social spaces where women could enjoy the same kind of freedom to be openly butch and fem, and many women did not want to endanger these spaces by calling in the authorities. The Continental was one of the few places where women felt relatively free from harassment; it was the outside world that was dangerous, especially when women traversed it alone ${ }^{80}$ As Lynn's testimony vividly illustrates, women who challenged the behaviour of a few known troublemakers put their own physical safety at risk. If their efforts failed, they might find themselves unable to access the community of people who made them feel most safe. Undoubtedly some women expressed their disapproval by simply retreating from the bar altogether, but for women committed to living the gay life, there was nowhere to retreat. ${ }^{81}$ The more women came to rely on the social networks that centred on the Continental, the more they risked by censuring their peers. Despite the damaging effect violence and abuse had on all women who participated in Toronto's lesbian bar culture, disagreements over how some women conducted their lives and treated their partners were rarely openly expressed. ${ }^{82}$

Jan, Father Murphy, Mitch, and their clique stand out in the memories of most narrators because their behaviour was the exception, not the rule. Still, most women agree that arguments among women in the bar were frequent and sometimes escalated into physical conflict. Yet remarkably, neither the Liquor Licensing Board of Ontario nor local police forces made any effort to close the bar down. As we now know, the postwar era was a period of widespread social anxiety about the threat of sex deviants, but it was men, not women, who were the primary targets. Up until the end of the 1950s, the police did not raid the Continental, and there are no records to suggest that any effort was made to force the owner or management to ban their lesbian customers even though liquor licensing laws contained provisions that allowed them to do so. ${ }^{83}$

Local authorities were keeping an eye on the Continental, but it was mixed race heterosexual couples that were of concern, not the "mannish," "husky," "he-shes" beginning to make it their home. Up until 1954, the LLBO enforced racial segregation in licensed establishments by treating "race-mixing" as a signifier for disorderly conduct. ${ }^{84}$ When Syrian-born Lenia Chamandy bought the Continental in 1948, she knew the previous owners were reprimanded for allowing non-white men to mingle with white women. ${ }^{85}$ Eager to reassure the 
Liquor Board that she intended to run a respectable business, her lawyer informed them "in order to improve the operation of the... beverage rooms, we have decided to eliminate mixed-race drinking ... [by which] we mean Chinese entering with white women, Negros with white women, etc." The LLBO continued to monitor the situation. In a 1952 spot check, it was noted that, "lately with increasing numbers Negro men have been congregating in front of this establishment and are picking up white girls." The LLBO inspector promptly informed the local police inspector, who reported that his officers were "trying to clear it up." 86 In the fall of 1955, an African Canadian man attempted to enter the Ladies and Escorts room with "an old white woman" but the staff refused them entry. There was nothing new in denying service to black Canadians, except that after 1954 it was a violation of the Fair Accommodations Act, and proprietors who refused service on the basis of race, creed, colour, nationality, ancestry, or place of origin could be fined ${ }^{87}$ With the law now ostensibly on his side, the aggrieved male patron alerted a journalist at the Toronto Telegram, a daily newspaper that offered supportive coverage of the Fair Accommodations Act the previous year. ${ }^{88}$ Although the LLBO file does not indicate how the Board responded to the incident, there were no further reports concerning mixed-race patronage.

It was around the same time that gay women moved from the Tenderloin on Jarvis Street to a public house at Elizabeth and Dundas Streets in Chinatown, but curiously, local liquor authorities made no formal complaints or even benign observations about the growing presence of the "sapphic set," even though some members of the set were African Canadian, and all mixed openly with Chinese sex trade workers inside the public house. ${ }^{89}$ When the police focussed their attention on gay women, it was usually a result of their involvement with the sex trade, theft, or public brawls such as the one that occurred near the Westminster Hotel. The police and the courts also made liberal use of established vagrancy laws to try to keep Continental regulars off the streets and away from the Tenderloin and Chinatown, but in the 1950s the police rarely entered the bar, and they never conducted the sort of "paddy wagon" raids and mass arrests commonly associated with gay bars in this period. Moreover, unlike gay men whose public cruising made them vulnerable to charges of gross indecency, downtowners were rarely caught having or pursuing sex with one another. When the police discovered two women necking in Riverdale Park in 1954, the same year the Criminal Code of Canada was revised to allow for women to be charged with gross indecency, the police charged "mannish" Patricia Hendrick under section C of the vagrancy laws, having no visible means of support. ${ }^{90}$ According to her testimony in court, she had not held a regular job for a year and supported herself as a prostitute. Hendrick was hauled off to prison, but her lover was never charged. Instead, Salvation Army Major Mabel Woollcott who promised to provide housing and 
help her find a job escorted her out of the court.

Even as other forms of sexual deviation (a modernized and medicalized term) became the subject of intense media, medical and social concern, in the 1950s lesbianism remained a lesser threat. ${ }^{91}$ With the exception of the scandal sheets, Canada's print media focussed almost exclusively on pedophilia and male homosexuals..$^{92}$ As late as 1962 the Associate Editor of Chatelaine, Canada's leading national women's magazine, rejected an article about lesbians of the "nasty practicing kind... After all," she wrote, "sex with men is what worries moms because it often ends up showing." the real sexual peril for young women. Despite warnings by American experts like Frank Caprio who insisted homosexuality was as dangerous in women as it was in men, Canadian experts were surprisingly blasé. ${ }^{94}$ During the 19541957 hearings of the Royal Commission on the Criminal Law Relating to the Criminal Sexual Psychopath, medical experts from across the country were called upon to give testimony on the problem of sexual deviancy. Only one witness bothered to comment on lesbianism. As far as Dr. J,N. Senn of Hamilton, Ontario knew, "The female homosexual conducts herself in such a way that she never comes to public attention," and he did not seem to think that there was any reason to "alter this situation."

Senn may not have been aware of the growing visibility of butch and fem lesbians and lesbian prostitutes in Canada's major urban centres, but Toronto's Chief of Police John Chisholm certainly was. Yet Chisholm was surprisingly circumspect about the sex panic that was driving anti-homosexual campaigns throughout Canada and the United States. Asked to testify on the problem of sex deviants in his city, Chisholm told the same commission that in his opinion motor vehicles were a greater threat to the safety of children than were sex perverts. Although his officers conducted sweeps on male homosexual haunts, he did not demonstrate the same kind of zeal as many of his contemporaries in other urban centres. ${ }^{96}$ Indeed, in the 1950 s gay women seemed to enjoy somewhat congenial relations with local officers. Ivy, whose work in the sex trade brought her into regular contact with the police, claims they never hassled her. In fact, she remembers a time when off-duty officers worked security at a wedding ceremony for two gay women. ${ }^{97}$ Ivy is the only narrator who offers such a positive assessment of gay women's relations with local police forces. However, downtowners who were regulars in the 1950s say surprisingly little about their relationship to the police.

Political corruption also contributed to the peace in the 1950s. Public houses and other licensed establishments generally received their permits in exchange for financial donations to the reigning Conservative Party. Fred Gardiner, a high profile criminal lawyer known for representing local gambling interests, managed these transactions. This explains why private unlicensed clubs like the Wheat Sheaf were very likely to be raided by the police, where- 
as public houses rarely had their licenses revoked, and were little bothered by local authorities. In the 1950s, women encountered the police on the streets, not in the bar. ${ }^{98}$

At the end of the $1950 \mathrm{~s}$, however, relations between downtowners, prostitutes and the police changed dramatically. In 1958 Chisholm committed suicide, and his replacement had a much different attitude toward urban vice in general, and homosexuals in particular. ${ }^{99}$ Chief James P. Mackey promoted long-time friend Herbert Thurston to the position of Inspector, who launched a sustained campaign against prostitutes and homosexuals. ${ }^{100}$ In 1959, Hush reported that two officers were assigned to the Tenderloin to "haul in all girls found loitering." The formal charge was causing a disturbance. Unlike section $\mathrm{C}$ of the vagrancy laws, the law against causing a disturbance allowed the police to arrest and detain any woman simply for being out on the street at night. "This gives the police a wide margin to work on," wrote the Hush journalist. "The babes are being swatted like flies." 101 Police efforts to put down urban vice are often prompted by public calls for a crackdown on sexual immorality, but in the early $1960 \mathrm{~s}$, it was the police that were trying to rouse public ire. In a 1963 interview with the Globe and Mail, Thurston complained that Torontonians "lack disgust" for homosexuals, and their indifference was contributing to the growth of the city's sex deviant population. ${ }^{102}$ This contrasted sharply with the sentiment among his officers who, according to a Maclean's report, "might beat deviates in disgust." 103

Thurston was also determined to prove that lesbians were as much of a threat as gay men. He described them as part of a community of deviants that included men and that in total numbered around 40000 . Lest citizens think that mannish looking women posed no danger, he ominously told the reporter that a female officer who "ventured into" the Jukebox, an unlicensed Yonge Street club that catered to a lesbian clientele, was informed that if she used the washroom, she would be raped. ${ }^{104}$ His squad "harassed the club out of existence." 105

Thurston was not exaggerating about the increasing visibility of homosexuals in certain parts of the city. In the early 1960s gay women suddenly had a greater variety of social spaces available to them and were more likely to be congregating beyond the invisible boundaries that marked off Chinatown from the rest of the city. The Jukebox was run by a straight male ex-con, but gay women and men were starting to open up their own clubs. Heather and Georgie, a mixed-race lesbian couple, opened The New Orient on Queen and Spadina where women could come for soft drinks and dancing. British-born musician Robin York and her partner opened the upscale Regency Club on tony Prince Arthur Avenue. ${ }^{106}$ Customers there enjoyed a piano bar, a pool table room and television room, a dance floor, and a café and patio. Perhaps the most important development was Sara Dunlop's persistent efforts, despite police 
harassment, to maintain an after-hours club. The Music Room, later renamed the Penthouse, drew lesbians to Yonge Street where they began to frequent restaurants and cafés nearby. Adult gay women quickly developed a following of younger women and together they made themselves at home in the front room of the Parkside Tavern, a bar that already had an established gay male clientele. However, while the Jukebox, Music Room, and Parkside provided an escape from the problems associated with the Continental, it also brought gay women physically closer to gay men. Male homosexuals were subject to greater police scrutiny, and drinking in bars and clubs where gay men congregated automatically increased the amount of contact, and the potential for conflict, between gay women and the police. ${ }^{107}$

Finally and most fatally, around the same time that Mackey was promoted to Chief of Police, heroin (and soon thereafter speed and pharmaceuticals) became as much a part of "the gay life" as prostitution. Downtowners and sex trade workers were some of the city's earliest users and dealers, and the Continental and surrounding neighbourhood quickly earned a reputation as a drug haven. ${ }^{108}$ The impact was profound. It changed the way women socialized; rather than become rowdy and boisterous from consuming alcohol, they became lethargic, lost their appetite, and began to show signs of physical deterioration. ${ }^{109}$ The cost of a single cap of heroin was six dollars, significantly more than a glass of beer, and women's participation in the sex trade and other illegal activities increased in order to support their addiction. ${ }^{110}$ By the end of the decade, countless women died as a direct or indirect result of drug use. ${ }^{111}$

Heroin also led to a dramatic increase in the level of police attention downtowners attracted. All levels of Canadian law enforcement, including the local Metropolitan Toronto police division, the Ontario Provincial Police, and the Royal Canadian Mounted Police (RCMP) actively participated in the effort to stop the traffic in illegal drugs, and in the 1960s gay women were more likely to encounter law enforcement officials than they had at any other time. In the late $1950 \mathrm{~s}$, four Toronto officers were assigned to the drug squad, and they made it their business to become intimately familiar with downtowners' comings and goings. ${ }^{112}$ They also worked in cooperation with other police organizations. ${ }^{113}$ Unconcerned with the system of political payoffs that kept the police out of public houses, the RCMP planted female informants in the Continental and other bars and restaurants. ${ }^{114}$ This was not the first time the RCMP assigned undercover agents to homosexual bars. During the 1950s, investigations of "subversion" in the civil service prompted the same force to use similar tactics to identify homosexuals. ${ }^{115}$

The intensity of police efforts and their willingness to use a wide range of methods of intimidation, including physical violence, made the gay life significantly more dangerous. Even women who were not involved in the drug trade 
104 Chenier

were affected. Neither Jerry nor Lynn used heroin or speed, but both were questioned about the drug trade. Lynn remembers one time when she was picked up by the RCMP and taken into the station:

The cops knew enough about everybody, they knew fuckin' well that I did not use, but they knew that my girlfriends did. So they figured that I must know who the pushers are and where this shit is coming from. I said, 'I don't fucking know nothing. I don't want to know nothing, I hate drugs. If you fuckin know so much, then you know I am only a drunk and I start drinking at 12 and by 12:30 I don't know my ass from a hole in the ground.' This one guy got his knuckles and he hit me right on the bone in the top of my skull here, bang! The tears came flying out of my eyes. And he took his big shoe, they wear steel toes ... [and kicked me] right in the shin. I still have a mark to this day on my shin. He was saying 'you know where she gets it you fucking little dyke.' And he'd smack me. And then he got his hand and he had my whole throat. I swear I could feel my eyes start to bug right out of my head and I started to panic inside. I got to where I really couldn't breathe, my tongue was coming out and I really thought I was going to die.

Eventually they released her, but not before warning her to stay away from the corners. Lynn ignored the warning.

Jerry confirms that if the police "thought that you were dealing in heroin, they didn't give a shit ... especially the horsemen [RCMP] ... if they got an address, they'd bust it." Like Lynn, she too was picked up off the street.

The cops knew who I was ... and this little bastard picked me up, told me to get into the car, so I did. And he was asking questions about somebody who was dealing heroin and I said, 'I don't fucking know who you're talking about.' He said, 'You don't eh?' Rack! ... This bastard hit me in the left arm and he broke it, broke it with a fuckin' billy club.

The police may have been vicious in their methods, but they were not wrong in their assessment. Lynn and Jerry both knew who was doing and who was dealing drugs, but refused to provide this information. Regardless of how much Lynn despised the drug trade, there was a general expectation that "you don't cop out somebody." 116 We might guess that some women succumbed to the pressure tactics the police employed. The RCMP searched Ivy's home on at 
least two separate occasions, possibly because they were acting on tips from other women. ${ }^{117}$

Arlene, who did deal in drugs, was also victimized by local police forces, although she never was charged with a drug-related crime. "Many [police officers] used to pick you up and kick your head in. It was a fun time; take you down to Cherry Beach and beat the shit out of you." Cherry Beach was a stretch of undeveloped land along Lake Ontario. Surrounded by heavy industry, it was deserted most nights. Its remote location made it popular among sex trade workers who sometimes took tricks there, but it was also used by local police officers to beat and rape prostitutes and downtowners. Lynn and Jerry were each taken there twice by the police and physically assaulted, Arlene was raped and left to make her way back into the city without the benefit of either clothes or shoes. ${ }^{118}$ No wonder Lynn felt that "all [the police] needed was the excuse that you were queer ... and that gave them the license to beat the living supreme shit out of you." Women's involvement relationship to sex trade and their involvement in petty theft and physical assault increased the likelihood that they would attract the attention of local police forces, but at the end of the 1950 s, the introduction of street drugs and the new Toronto police chief's more aggressive anti-homosexual stance made those interactions more frequent and more violent.

These accounts confirm our worst fears about the way lesbians and gay men were treated by the police in the postwar period, but they also reveal that some women were much more likely to be targeted by the police than others. As downtowners grew increasingly fearful of the police, uptowners remained astonishingly confident that they would have no trouble with the law. They also understood that the police did not target gay women indiscriminately, but directed their attention toward downtowners. So long as they did not participate in illegal activities or carry weapons, uptowners were certain that they would never be harassed. Instead, they were more likely to fear being identified by "tourists," men and women who came to the Continental to gawk at the lesbians. ${ }^{119}$ But not even that troubled Denise and Lois Stewart. The daughter of Italian immigrants who ran a neighbourhood fruit market in the west end, Denise was very careful about her family's reputation, and placed a high value on sexual discretion and privacy. Yet she had no misgivings about going to the Continental in the 1960s because she was certain no one she knew would ever come to such a dive. As a middle class schoolteacher, Lois understood that being seen in a bar with a lesbian crowd would bring her career to an abrupt end, but since she worked in another city, she decided the risk was small. For her, the Continental posed little danger at all. "Most of the people knew about [us] and we didn't get much flack," she explains. "Not in that place .... We could spot a tourist a mile off, they'd watch us, but the rest of the people in the bar were used to us. That's why we went there. You could go there reasonably 
safely." ${ }^{20}$ The same applied to the police, who she said, would "often arrest everyone in the place except me and a couple others. Because they all knew who we were. Everyone knew ... I didn't deal drugs and they knew it."121 Indeed, not one of the four uptowners that inform this study were ever bothered by the police. ${ }^{122}$

Participating in Toronto's lesbian bar culture demanded that uptowners (and downtowners) accept or at the very least turn a blind eye to a variety of activities that they might otherwise find objectionable. ${ }^{123}$ They had to sit alongside prostitutes, johns, and rounders without passing judgement, and they had to learn the rules of discretion that governed a street economy subject to police and state regulation. Most women accomplished this by keeping a distance from downtowners. Beth claims, "As long as you didn't interfere with other people you didn't know or didn't want to know, you were fine." Even those keen to cultivate friendships with downtowners developed social strategies to shield them from trouble. Lois Stewart prided herself on her ability to cross the "invisible line" that separated the two groups but refused to give downtowners a ride in her car for fear that they might stash drugs in it. ${ }^{124}$ On the whole, most downtowners maintained cordial, but not intimate, relations with uptowners. ${ }^{125}$ Downtowners kept them at a distance, and when they took offence to uptowners' conduct, were willing to use physical force and intimidation to drive them out. ${ }^{126}$ Mutual distrust and sometimes disdain marked the uneasy relationship between uptowners and downtowners. However great their shared experience of social isolation and their common interest in sexual relations with other women, there were other forces at work that precluded the creation of a unified community bound together by their status as sexual outsiders. At the Continental Hotel, some were much further outside than others.

Two years after Joji Hazel visited the Continental, an anonymous writer offered a playfully affectionate description of the downtown butch:

When a female baby doesn't outgrow dirty denims, scuffed shoes, chain smoking and picking fights and acquires so much brashness that her family doesn't dare introduce her to their friends, she becomes a butch .... She is a piece of skin stretched over a rebellion. A war on two legs .... She is a confused situation to be cuddled, fed, liquored, and loved at all times: a boy forever, a policeman's nemesis, the offspring of our times, the scourge of a nation. Every one molded is a taunt that woman can equal man .... If not worked too often and if praised at regular intervals will survive fights, thirty days for vagrancy, starvation, hangovers and a hard night of love. ${ }^{127}$ 
Ironically, at the same time 'What is a Downtown Butch' was published, the conditions that created downtowners as a distinct social group were unravelling. Chinese married bachelors were aging; those still living were moving out of the neighbourhood entirely, and Chinatown's sex trade workers gradually returned to the Tenderloin. ${ }^{128}$ After the mid-1960s, lesbians were more likely to congregate in the bars, clubs, and restaurants around the Music Room and Parkside on Yonge Street, or in even newer bars on Church Street and in the city's east end. ${ }^{129}$ The Continental developed a reputation as a place where the older crowd hung out. When its doors finally closed in 1975, a new generation of lesbians offered an entirely different "taunt that woman can equal man."130 Though gay women's involvement in the sex and drug trades did not end in the 1960s, the maintenance of a public lesbian bar culture would no longer depend on the illegal economy to sustain it. And with the rise of lesbian-feminism in the 1970 s, new social divisions emerged to displaced uptowners and downtowners as one of the primary categories of difference.

According to one of sociologist Jo Anne Pratt's informants, living openly as a butch lesbian was "an indication of pride in the homosexual way of life." "131 It also meant exposing oneself to economic and social peril. Limited job options drove women to pursue opportunities available to them in some of the city's rougher bars, and time spent in rough bars guaranteed exposure to verbal conflict and physical danger. So long as women remained dependant on the street economy, they remained wedded to street bars. Tough bar lesbians did not congregate in street bars because they wanted to expand the number of spaces available to women, as Davis and Kennedy argue. Nor were they attracted to them because they were necessarily familiar environments. Existing sex trade cultures provided the conditions necessary for gay women to establish themselves as a regular and stable presence, but tough bar lesbians preferred street bars because the sex trade also provided opportunities to combine remunerative labour with pleasure. Downtowners were homosexual, but expressions of gender and sexual identity were informed by the economic consequences of living the gay life full time. As a result, downtowners were much more aggressively policed by law enforcement officials, and much more likely to come into conflict with the law. Their intimate familiarity with prostitution, drugs, and local Chinese men established firm boundaries between themselves and other gay women whose sexual identities bore no apparent relationship to other local, marginalized groups. In the 1950s and 60s being gay "at all times" generated strategies of survival, rules of discretion, and forms of social discourse that set downtowners apart from other working-class lesbians. 
This author would like to thank the editors of Left History and the anonymous reviewers for their thoughtful critical commentaries and suggestions on an earlier and much different version of this article. I am especially indebted to Marc Stein, Steven Maynard, and Suzanne Morton for their helpful comments at a critical stage in the preparation of this paper. I would also like to thank the Lesbians Making History collective for granting me permission to use their interview collection, the women who generously granted interviews, and "Jerry" for tolerating more than a decade of prying questions. Lois Stewart, Ivy, and Lynn are all the real names of narrators. All others are pseudonyms, either at the request of the interviewee or because permission was not obtained at the time the interview was conducted. The Lesbians Making History collection, to which I have added my own interviews, is currently being prepared for donation to the Canadian Lesbian and Gay Archives in Toronto, Ontario. Anyone interested in contributing their own history to this collection should contact the author at the Department of History, Simon Fraser University.

Notes

1 Joji Hazel, "Main St.- Lesbianville," The Ladder, May 1963, p. 22.

2 On lesbian images in pulp fiction see Kate Adams, "Making the World Safe for the Missionary Position: Images of the Lesbian in Post-World War II America" in Lesbian Texts and Contexts: Radical Revisions, ed. Karla Jay and Joanne Glasgow (New York: New York University Press, 1990), 255-274; see also Forbidden Love: The Unashamed Stories of Lesbian Lives, dirs. Lynne Fernie and Aerlyn Weissman, 84 mins., National Film Board, 1992, videocassette; Donna Penn, "The Meanings of Lesbianism in PostWar America" Gender and History 3:2 (Summer 1991), 191.

${ }^{3}$ Hazel, "Main St.- Lesbianville," 22.

${ }^{4}$ Historians typically describe participants in lesbian bar cultures as members of a bar "community," but the homogeneity this term implies is misleading. For useful suggestions about how historians might rethink community as a category of analysis, see John C. Walsh and Steven High, "Rethinking the Concept of Community," Historie sociale/Social History 32, 64 (1999): 255-273. The meaning of butch and fem roles have been the subject of much debate, and the sources are too many to list here. For a brief summary of some of the key arguments, readers should consult Elizabeth Lapovsky Kennedy and Madeline Davis, Boots of Leather, Slippers of Gold: A History of a Lesbian Community (New York: Routledge, 1993), 152-4.

5 Gay men used the term "the double life" to refer to the same practice decades earlier. See George Chauncey, Gay New York: Gender, Urban Culture, and the Making of the Gay Male World, 1890-1940 (New York: Basic Books, 1994), 273-280.

6 The gay life is different from the "gay world" described by George Chauncey. Both uptowners and downtowners entered the gay world, but only downtowners lived the gay life. Chauncey, Gay New York, 7.

${ }^{7}$ Of the women who inform this study, Denise was the only one to describe a personal relationship that involved "cross-class" dating. Her partner adapted to Denise's life of privacy and discretion, but when at the Continental her friendships kept her tied to the downtowner social circle. Consequently, Denise socialized with downtowners when 
they went together, though she did not consider herself one of them. Denise, interview by author, Toronto, 1993.

${ }^{8}$ In some cities women who refused to be either butch or fem, and women who switched from one gender identity to the other, were called "kiki." Toronto lesbians did not appear to use that name. One gay woman who was active in the bar scene at the time liked to call herself "an opportunist." Carole Ritchie-Macintosh, interview by author, Toronto, 1992. On the use of "kiki," see Kennedy and Davis, Boots of Leather, Slippers of Gold, 212, 213; Lillian Faderman, Odd Girls and Twilight Lovers: A History of Lesbian Life in Twentieth Century America (New York: Columbia University Press, 1991), 175-84

${ }^{9}$ Kennedy and Davis, Boots of Leather, Slippers of Gold, chapter 4. Women in Toronto also referred to uptowners as "the elite."

10 "They don't call the Saturday-night butches he-shes. It means something. It's a way we're different. It doesn't just mean we're ... lesbian." Leslie Feinberg, Stone Butch Blues (New York: Firebrand Books, 1993), 147-8. The main character also suggests that there were similar distinctions between sex trade workers. Her lover's status as a "pro" set her apart from other prostitutes who were ashamed of their work in the sex trade.

11 Katie Gilmartin, " 'We Weren't Bar People': Middle Class Lesbian Identities and Cultural Spaces," GLQ 3 (1996): 24-5. Here I have adopted Davis and Kennedy's use of the term upwardly mobile to denote women who lived a public life of discretion but who went to bars nonetheless.

12 Janet Kahn and Patricia A. Gozemba, "In and Around the Lighthouse: Working Class Lesbian Bar Culture in the 1950s and 1960s," in Gendered Domains: Rethinking Public and Private in Women's History: Essays from the 7th Berkshire Conference on the History of Women, ed. Dorothy O. Helly, Susan M. Reverby (Ithaca, NY: Cornell University Press, 1992), 94. See also Faderman, Odd Girls and Twilight Lovers, 182.

${ }^{13}$ Faderman, Odd Girls and Twilight Lovers, 182-3; Marc Stein, City of Sisterly and Brotherly Loves Lesbian and Gay Philadelphia, 1945-1972 (Chicago: University of Chicago Press, 2000), 59, 78. Gay and lesbian public spaces were also defined by processes of racialization, but research in Toronto has yet to uncover a commercial space where gay women of colour enjoyed majority status.

14 See for example Sara Crawley, "Are Butch and Fem Working-Class and Antifeminist?" Gender and Society 5.2 (April 2001), 188.

${ }^{15}$ On the upwardly mobile see Kennedy and Davis, Boots of Leather, Slippers of Gold, 133-138. The emergence of the tough bar lesbian is the subject of chapter two; tensions between the two groups are discussed on 138-145.

16 Ibid., 145.

17 For a similar examination from the perspective of middle class lesbians, see Gilmartin, " "We Weren't Bar People'."

${ }^{18}$ Among the most significant American studies to use oral history are Davis and Kennedy, Boots of Leather, Slippers of Gold; Chauncey, Gay New York; and Stein, City of Sisterly and Brotherly Loves. For an assessment of the tabloids as a resource for historians, see Ross Higgins and Line Chamberland, "Mixed Messages: Gays and Lesbians in Montreal Yellow Papers in the 1950s," in The Challenge of Modernity: A Reader on Post-Confederation Canada, ed. Ian MacKay (Toronto: McGraw-Hill Ryerson, 1992), 421-38 and Stephen Maynard's. "Hell Witches in Toronto': Notes on Lesbian Visibility 


\section{Chenier}

in Early Twentieth-Century Canada," in this issue.

${ }^{19}$ John D'Emilio, Sexual Politics, Sexual Communities: The Making of a Homosexual Minority in the United States, 1940-1970 (Chicago: University of Chicago Press, 1983), 31-32. See also Allan Bérubé, Coming Out Under Fire: The History of Gay Men and Women in World War Two (New York: Free Press, 1990). Paul Norman Jackson details a similar effect in Canada in "Courting homosexuals in the military: The management of homosexuality in the Canadian military, 1939-1945" (PhD diss., Queen's University at Kingston, 2002).

${ }^{20}$ George Chauncey's similarly comprehensive study of New York before World War Two challenges D'Emilio's thesis by arguing that in pre-World War Two era, gay life in New York enjoyed greater visibility to outsiders and greater social tolerance than in the post-World War Two era. Boyd's more recent contribution suggests that in San Francisco women were also successful in forging queer public spaces in that city's urban sexual geography. See Chauncey, Gay New York, 9, 10 and Nan Alamilla Boyd, Wide Open Town: A History of Queer San Francisco (Berkeley: University of California Press, 2003).

${ }^{21}$ Davis and Kennedy, Boots of Leather, Slippers of Gold, 38-9.

22 "Lisa Ben," "Here to Stay," Vice Versa (September 1947), 5.

${ }^{23}$ David Sobel and Susan Meurer, Working at Inglis: The Life and Death of a Canadian Factory (Toronto: James Lorimer and Company, 1994), 66-68.

${ }^{24}$ Margaret, interviewed by author, Toronto, Ontario, 1995.

25 Ibid. Remarkably, Margaret claims that it was not until 1993 when she saw the Canadian documentary Forbidden Love that she first understood herself as a lesbian. Karen Duder describes similarly isolated lesbian couples in "The spreading depths: Lesbian and bisexual women in English Canada, 1910-1965," (PhD diss., University of Victoria, 2001), 362. On friendship networks among professional women in Ontario, see Kato Perdue, "Dear Lamb, I Am At Your Feet," unpublished paper presented at Passion in Prose: Love Letters from the Queer Past, University of Toronto, June 2001.

${ }^{26}$ On industrial baseball leagues see Sobel and Meurer, Working at Inglis, 69; on lesbians and organized ball teams in Toronto see Trisha, interviewed by Lesbians Making History (LMH), [Toronto?], 1986; on ball teams and lesbians in Kingston, Ontario see Marney Elizabeth McDiarmid, "From Mouth to Mouth: An Oral History of Lesbians and Gays in Kingston from World War II to 1980," (MA thesis, Queen's University at Kingston, 1999); on the gay beach on the Toronto Island see Forbidden Love. On Hanlan's Point, see Becki Ross, "Dance to 'Tie a Yellow Ribbon,' Get Churched, and Buy the Little Lady a Drink: Gay Women's Bar Culture in Toronto, 1965-1975," in Weaving Alliances: Selected Papers Presented for the Canadian Women's Studies Association at the 1991 and 1992 Learned Societies Conferences, ed. Debra Martens (Ottawa: Canadian Women's Studies Association, 1993), 272.

${ }^{27}$ In an interview with $\mathrm{LMH}$, two downtowners recall visiting the Wheat Sheaf but no details are offered. Jerry, also a downtowner, was too young to have gone there, but recalls hearing about it many years after it closed. Jerry, interview by author, Toronto, 2004.

${ }^{28}$ Donald Kerr and Jacob Spelt, The changing face of Toronto: a study in urban geography (Ottawa: Geographical Branch, Mines and Technical Surveys, 1965), 130; "Women Workers in Canada, 1954-1964," Labour Gazette 65 (April 1965), 65. 
29 Tamara Adilman, "A Preliminary Sketch of Chinese Women and Work in British Columbia, 1858-1950," in British Columbia Reconsidered: Essays on Women, ed. Gillian Creese and Veronica Strong-Boag (Vancouver: Press Gang Publishers 1992), 309-339; Dionne Brand, " 'We Weren't Allowed to Go Into Factory Work Until Hitler Started the War': The 1920s to the 1940s," in "We're Rooted Here and They Can't Pull Us Up": Essays in African Canadian Women's History, ed. Peggy Bristow et al. (Toronto: University of Toronto Press, 1994), 171-192.

${ }^{30}$ See Elaine Tyler May Homeward Bound: American Families in the Cold War Era (New York: Basic Books, 1988); Mary Louise Adams, The Trouble with Normal: Postwar Youth and the Making of Heterosexuality (Toronto: University of Toronto Press, 1997) and Annalee Golz, "Family Matters: The Canadian Family and the State in the Postwar Period," left history 1:2 (1994): 9-49. On post-World War Two labour trends among women see Veronica Strong-Boag, "Canada's Wage Earning Wives and the Construction of the Middle Class, 1945-1960," Journal of Canadian Studies 29:3 (1994): 5-25.

31 Jerry, interview by author, Toronto, 1992.

${ }^{32}$ Lynn, interview by author, Toronto, 1993; Jerry, interview (1992); Jan, interview by LMH, [Toronto?], 1985; Arlene, interview by LMH, [Toronto?], 1987. See also Becki Ross, "Destaining the (Tattooed) Delinquent Body: The Practices of Moral Regulation at Toronto's Street Haven, 1965-1969," Journal of the History of Sexuality 7:4 (April 1997): 591.

${ }^{33}$ Feinberg's Stone Butch Blues offers insight into the type of work patterns and problems experienced by butch women who lived the gay life full time. One of the problems that plagued downtowners was combining late night drinking with a full time job. See Jerry, interview (1992). Lynn remembers that she was never able to hold down a job because when she was at work, she went crazy thinking about the action she was missing in and around Chinatown. Lynn, interview.

${ }^{34}$ Arlene, interview.

35 Ibid.

36 Two charges were for crimes committed against themselves, one for attempted suicide and the other for overdosing on sleeping pills. Jo Anne Pratt, "A Study of the Female Homosexual Subculture," (MA thesis, School of Social Work, University of Toronto, 1964), 42.

${ }^{37}$ Arlene broke into cars to sleep, Jerry was arrested outside the New Orient during a lover's quarrel, and Lynn was told not to return to the corners after being interrogated by the RCMP. See Arlene, interview; Jerry, interview; Lynn, interview.

38 Pratt, "A Study of the Female Homosexual Subculture," 8-9.

39 See especially Donna Penn, "The Lesbian, the Prostitute, and the Containment of Female Sexuality in Postwar America," in Not June Cleaver: Women and Gender in Postwar America, 1945-1960, ed. Joanne Meyerowitz (Philadelphia: Temple University Press, 1994), 358-379; Joan Nestle, A Restricted Country (New York: Firebrand Books, 1987); George Chauncey, Gay New York, 33-45, 131-2 and “The Policed: Gay Men's Strategies of Everyday Resistance in Times Square" in Creating a Place for Ourselves: Lesbian, Gay and Bisexual Community Histories, ed. Brett Beemyn (New York: Routledge, 1997), 9-25; Steven Maynard, "Horrible Temptations: Sex, Men and Working-Class Male Youth in Urban Ontario, 1890-1935," Canadian Historical Review 


\section{Chenier}

78.2 (June 1997), 210; Boyd, 25-101. Vanessa Cosco, “ 'Obviously Then I'm Not Homosexual:' Lesbian Identities, Discretion and Communities in Vancouver, 19451969" (BA thesis, University of British Columbia, 1997); also Forbidden Love (NFB, 1992).

40 Jan, interview; see also Jean in Forbidden Love (NFB, 1992).

${ }^{41}$ On similar practices of gender segregation in Vancouver, see Robert A. Campbell, "Managing the Marginal: Regulating and Negotiating Decency in Vancouver's Beer Parlours, 1925-1954," Labour/Le Travail 44 (1999): 109-127.

${ }^{42}$ In the 1930s Toronto police constables working the night shift were required to check in on the city's downtown hotels at closing time when fights were most likely to occur. James P. Mackey, "I Policed Toronto": An autobiography by James P. Mackey, Chief of Police, Metropolitan Toronto, 1958-1970 (1985), 18.

43 Ontario Archives, RG 36-8 Establishment Files, "Lamb's Star Hotel," report by Inspector W.H. Cool, 28 July 1947. In 1948 The Lamb's Star was renamed the Continental Hotel.

44 "Five Women Assault Man," Justice Weekly, 2 August 1952, p. 2, 13.

${ }^{45}$ For example, in the 1930s a group of "gypsies" ran a fortune telling business out of a storefront location in Chinatown. Provocatively costumed woman sat perched in the window to lure male customers. Over the years a number of men, including at least one Ontario city mayor, filed criminal charges claiming that their wallets were stolen while their future was being foretold. See Mackey, 21. City maps show that an "aura reader" maintained residence in the neighbourhood into the 1950s. Archives of Ontario, "Toronto FIPS," 1954.

${ }^{46}$ For a brief description of the practice, see Pratt, "A Study of the Female Homosexual Subculture," 43. See also Jerry, interview (1992).

47 "Jap Says Four White Young Girls Picked Him Up In Car And Robbed Him of \$27 After Assaulting Him" Justice Weekly, 22 September 1956, p. 2, 16. The reporter noted that all of their supporters "flaunting themselves as Lesbians" were white with the exception of a "husky young negress, wearing jeans, of course, and her hair closely cropped." Interestingly, the four women wore "female garb" for their court appearance. Perhaps the reporter would not have identified them as lesbians had their friends not been in the courtroom. Joan Nestle's claim that New York fems were sometimes mistaken for butches suggests that it is possible reports about "mannish" women may have included fems. Nestle, A Restricted Country, 100, 102.

${ }^{48}$ Ontario liquor licensing laws prohibited female staff from serving alcohol. Unlike American bars where owners hired gay women as bartenders in order to encourage a lesbian clientele, this was not possible in Ontario until the early 1970 s.

49 Jerry, interview (1992); Denise, interview.

50 Jerry, interview $(1992,2004)$.

${ }^{51}$ Lynn, interview.

${ }^{52}$ Arlene, interview.

${ }^{53}$ For another account of the team approach to rolling tricks, see "Bargain Chippy Had Sour Taste," Confidential Flash, 9 July 1955, p. 5.

${ }^{54}$ Jerry, interview (1992).

${ }^{55}$ Pratt, "A Study of the Female Homosexual Subculture," 43. 
${ }^{56} \mathrm{Ibid}$. See also Ivy, interview by author, Toronto, 1993.

${ }^{57}$ On the regulation of condoms and other forms of birth control in this period, see Angus McLaren and Arlene Tigar McLaren, The Bedroom and the State: The Changing Practices and Politics of Contraception and Abortion in Canada, 1880-1997, $2^{\text {nd }}$ ed. (Toronto: Oxford University Press Canada, 1997).

${ }^{58}$ Jerry became pregnant with twins and like many other downtowners, gave her children up for adoption. Jerry, interview (1992).

${ }^{59}$ William Weintraub, City Unique: Montreal Days and Nights in the 1940s and '50s (Toronto: McClelland and Stewart, 1996), 59-87. See also Higgins and Chamberland, "Mixed Messages," 422.

${ }^{60}$ Jack Webster, interview by author, Toronto, 1994. Webster also recalls two unsolved murder investigations involving lesbian victims, though there is no evidence directly linking the victims to male pimps.

${ }^{61}$ See "Lesbian Beat Murder Trial Now Stabs Man," Flash, 7 January 1956, p. 1, 8; "Lesbian Quintet Dream Up Attempted Rape Story to Cover Up Knife Wound," Justice Weekly, 28 July 1956, p. 3, 16; "Toronto Breeze Around" Hush Free Press, 23 August 1958 , p. 5.

${ }^{62}$ Webster, interview. After World War Two, white Torontonians were more willing to patronize Chinese owned and operated restaurants and teahouses, but usually only during daylight hours. After dark, the streets were alive with activity, but it was a narrow cross-section of people who felt at home in the Elizabeth and Dundas Streets area.

63 Valerie A. Mah, "The 'Bachelor' Society: A look at Toronto's early Chinese Community from 1878-1924" Part II Student paper, "Independent Research," Multicultural History Society of Ontario (April 1978), 18. On prostitution in Vancouver's Chinatown in the early twentieth century, see Adilman, "A Preliminary Sketch of Chinese Women and Work in British Columbia, 1858-1950," 309-339.

${ }^{64}$ Peter S. Li, The Chinese in Canada (Toronto: Oxford University Press, 1998).

${ }^{65}$ Ibid., 97.

${ }^{66}$ Justice Weekly, 3 July 1954, p. 5.

67 "Aged Chinese Wins Marilyn," Hush Free Press, 12 September 1959, p. 6.

68 "Lesbians Overflow Chinatown," Hush Free Press, 28 November 1959, p. 12.

${ }^{69}$ See also Ross, "Destaining the (Tattooed) Delinquent Body."

${ }^{70}$ Lois, interview by LMH, [Toronto?], 1985.

71 Perhaps this was because he feared contracting a sexually transmitted disease. According to Jerry, genital crabs were rampant. Jerry, interview (1992).

${ }^{72}$ Ibid.

${ }^{73}$ Lois, interview.

${ }^{74}$ Ivy, interview; Lynn, interview. Buffalo women also pimped. See Davis and Kennedy, Boots of Leather, Slippers of Gold, 119.

${ }^{75}$ Lynn, interview.

${ }^{76}$ Arlene explains that when a friend first offered to bring her to the Continental, she insisted that Arlene first learn how to fight. Not all women had the benefit of anticipating violence, however, but neither were all women similarly attacked. Arlene, interview.

77 Ivy, interview.

${ }^{78}$ Denise, interview. 


\section{Chenier}

${ }^{79}$ Arlene, interview; Jerry, interview (2004). It is interesting that of all the women interviewed, "Jan", a pseudonym, is the only woman who is known by her first and last names, and narrators always use both when referring to her. This may be simply because there was more than one "Jan," but we might speculate that her willingness to reveal her full identity heightened her status as a fearless (and reckless) person.

${ }^{80}$ The opposite was true for most uptowners. Because they lived the double life, the danger they faced on the street and in the workplace was the same experienced by all women, whereas those who lived the gay life were much more likely to be verbally and physically assaulted as lesbians.

${ }^{81}$ See especially Stone Butch Blues, a semi-autobiographical account of the life and demise of butch-fem bar culture in Buffalo and New York. Author Leslie Feinberg details the difficulty of living butch after the demise of a stable bar community.

82 Of course, the same was true for heterosexuals. The issue of abuse among women stands out largely because we are more likely to imagine women as victims, not as perpetrators of violence. Women like Eve also made that assumption. After leaving an abusive marriage, she responded positively to a butch's advances because she assumed that a woman would not assault her. Unfortunately she was wrong; her partner physically abused her on many occasions, though always behind closed doors. Eve, interview by author, Toronto, 1993.

${ }^{83}$ Kennedy and Davis report that police raids of lesbian bars in Buffalo were rare and that after-hours clubs were more likely to be raided. Kennedy and Davis, Boots of Leather, Slippers of Gold, 41-2. On police raids of lesbian bars in other American cities in the 1950s and 1960s, see Faderman, Odd Girls and Twilight Lovers, 164-66; Stein, City of Sisterly and Brotherly Loves, 274-77; Boyd, Wide Open Town.

${ }^{84}$ For more on this practice see James W. St. G. Walker, 'Race,' Rights and the Law in the Supreme Court of Canada (Toronto: The Osgoode Society for Canadian Legal History and Wilfred Laurier University Press, 1997); in Philadelphia, "disorderly conduct" was the most common charge against lesbians and gay men, and justified coffeehouse raids on the basis of homosexuality, race-mixing, and drug use among patrons. Stein, City of Sisterly and Brotherly Loves, 50, 155-176.

${ }^{85}$ Lenia Chamandy was born in 1887 , and appears to have had little involvement in the management of the Hotel. All of the correspondence in the LLBO file is from her lawyer, usually written on behalf of a male relative. Narrators identity Johnny Roussy as the manager, though his title was head waiter. Whether or not he had a financial interest in the hotel is unknown. See Archive of Ontario, RG 36 Series 8, Establishment Files 1927-1961, "Continental Public House."

${ }^{86}$ (AO) RG 36 Series 8, Establishment Files 1927-1961, Box 92, 'Continental Public House' Spot Check, 6 September 1952.

${ }^{87}$ Backhouse, Colour-Coded, esp. chapter 7. On the Fair Accommodations Act see Ross Lambertson, “"The Dresden Story': Racism, Human Rights, and the Jewish Labour Committee of Canada," Labour/Le Travail 47 (Spring 2001): 43-82.

88 (AO) RG 36 Series 8, Establishment Files 1927-1961, Box 92, 'Continental Public House' Letter from Edward Chamandy to LLBO, 6 October 1955.

${ }^{89}$ Hush Free Press and Justice Weekly include descriptions of black butch and fem women among the predominantly white downtowner crowd, and narrators also recall their presence, but the collection of interviews this study draws provides testimony from 
women of white heritage, with the exception of Jan, who was part French and part First Nations. We need to learn more about the way race and racism influenced and organized women's lives, but I believe we can safely assume that women of colour, especially African-Canadian women, were more likely to be picked up on the street by the police and either harassed or formally charged with vagrancy. In the mid-1960s a black woman opened The New Orient, an unlicensed lesbian dance club, with her white girlfriend, and most of the patrons were the white Continental regulars. This suggests that city streets were more dangerous for women of colour than the bar was hostile to their presence. See Davis and Kennedy who found that 'street bars' were much more racially mixed than other types of bars, and that black women were much more likely to be harassed by the police than were white women, Boots of Leather, Slippers of Gold, 116, 122,127 . On Chinese sex trade workers, see Ivy, interview.

90 "Two Girls Necking in Park," Justice Weekly, 3 July 54, p. 2, 15. Eight years later the police raided a west end home where the female resident offered paying customers card games and alcohol. The police found two women engaging in sex together in one of the bedrooms. They laid charges of gross indecency, not vagrancy. The women were fined $\$ 500$ each. "CADI Who Freed Socialite Madam 'Tosses Book' At Female Lovers," Hush Free Press, 17 February 1962, p. 11.

91 See also Del Martin and Phyllis Lyon, Lesbian/Woman, 6th ed. (San Francisco: Bantam Books, 1983), 204.

${ }^{92}$ On media coverage of sex crimes and perversion in 1950s Toronto see Elise Chenier, "Seeing Red: Immigrant Women and Sexual Danger in Cold War Canada," Atlantis: A Women's Studies Journal 24:2 (Spring 2000): 51-60; Kathryn Campbell, "Deviance, Inversion and Unnatural Love:' Lesbians in Canadian Media, 1950-1970," Atlantis: A Women's Studies Journal 23:1 (Fall/Winter 1998): 128-136.

${ }^{93}$ Cited in Valerie J. Korinek, "Don't Let Your Girlfriends Ruin Your Marriage: Lesbian Imagery in Chatelaine Magazine, 1950-1969," Journal of Canadian Studies 33.3 (Fall 1998): 88.

${ }^{94}$ Although lesbianism was not directly addressed, there was a tremendous emphasis on the importance of raising "normal" children, which ultimately influenced social perceptions of gender transgression. See Mona Gleason, Normalizing the Ideal: Psychology, Schooling, and the Family in Postwar Canada (Toronto: University of Toronto Press, 1999). Frank S. Caprio, Female Homosexuality: A Psychodynamic Study of Lesbianism (New York: Citadel Press, 1954).

95 National Archives of Canada, Dr. J.N. Senn, reporting to the Royal Commission on the Criminal Law Relating to the Criminal Sexual Psychopath. RG 333/131 Acc 83$84 / 253$ v. 2.

96 This is not to suggest that the police did not target homosexuals as a group under Chisholm's watch. For a more critical assessment of Chisholm's testimony to the Commission, see Kinsman, The Regulation of Desire, 190-91.

${ }^{97}$ Ivy, interview.

${ }^{98}$ Sometimes the police simply parked their car outside the bar and waited for women to leave. Women tried to avoid getting harassed by either leaving through the back door, or leaving in large groups. See Arlene, interview.

99 Jocko Thomas, From Police Headquarters: True Tales from the Big City Crime Beat (Toronto: Stoddart, 1990), 164-173. 


\section{Chenier}

${ }^{100}$ Gary Kinsman, The Regulation of Desire: Homo and Hetero Sexualities, $2^{\text {nd }}$ ed. (Montreal: Black Rose Books, 1996), 228.

101 "Tenderloin Overflow," Hush Free Press, 20 June 1959, p. 7.

102 Globe and Mail, 14 November 1963, p 13. Using the news media to try to rouse public support for cracking down on homosexual clubs was denounced in an article in Two when the police repeated this tactic in 1965. "Who ... Us?" Two 3 (1965), 4, 31.

103 F. Russell, "Clinic to Curb Sex Crimes Before they Happen," Maclean's, 23 September 1961, p. 47.

104 Perhaps Thurston concocted this story himself in order to exploit the pulp novelstereotype of lesbians as sexual predators. In the context of the news story, it is clear that the comment is placed there to serve exactly this purpose. However, evidence suggests that gay women also used the stereotype for their own strategic purposes. In 1966 a social work student studying lesbians in Toronto reported that a gay woman sharing her table at the Continental made sexually suggestive facial gestures while reading aloud a want ad for a counsellor at a girls camp. In Forbidden Love, one of the narrators explains how heterosexual couples came to the Vanport to watch the lesbians. Gay women sometimes tried to frighten them away by following the women into the washroom, with the sole intention to causing her male partner anxiety over his wife or girlfriend's sexual safety. Though coercive sex and consensual washroom sex certainly took place, the image of the butch lesbian as a sexual predator was a ubiquitous stereotype that was exploited by gay women as well as those who policed them.

105 On other clubs similarly "harassed out of existence" in this period, see Donald W. McLeod, Lesbian and Gay Liberation in Canada: A Selected Annotated Chronology, 1964-1975 (Toronto: ECW Books/ Homewood Press, 1996), 9.

106 Lesbian and Gay Heritage of Toronto, Canadian Gay Archives Publication No. 5: 1982; "The Regency Club," Two 1 (1964), 15.

107 Davis and Kennedy also make this argument. See Davis and Kennedy, Boots of Leather, Slippers of Gold, 147; Stein explores the complexity of the relationship between gay men and lesbians in chapters two and ten of City of Sisterly and Brotherly Loves.

108 Both Jan and Arlene were drug dealers. In an article titled "Functions of Argot Among Heroin Addicts," a Toronto police officer used his long term connection with the city's "criminal subculture" to find research subjects. He includes downtowners among the "rounders" (members of the "criminal underworld") in his study, which found that the argot used by heroin addicts was "common to the whole criminal element." Of course, slang would have further divided uptowners from downtowners. See Lloyd G. Hanley [pseud.], "Functions of Argot Among Heroin Addicts," in The Underside of Toronto, ed. W.E. Mann (Toronto: McClelland and Stewart, 1970), 294307.

${ }^{109}$ Davis and Kennedy note that drugs negatively affected the African American lesbian house party scene. Drug users had no interest in eating the food and drinking the liquor that made such parties possible and profitable. Boots of Leather, Slippers of Gold, 130. 110 Hush Free Press, 29 March 1958, p. 5

111 Ivy thinks she was one of the very first women at the Continental to become addicted to heroin - she says it helped her deal with turning tricks, and attributes her survival to an early decision to kick the habit. Lynn remembers a night when she and some friend 
decided to draw up a list of all the women they knew who died from drug related causes. By the time they were done, the list included more than fifty names. Toronto's Street Haven actively outreached to this community. For a critical assessment of Street Haven's work with gay women, see Ross, "Destaining the (Tattooed) Delinquent Body," 561-595. Ross' review of the Haven's case files confirms both the prevalence and deadly impact of heroin use - see p. 591.

${ }^{112}$ Hanley, "Functions of Argot Among Heroin Addicts," 294-307.

113 Webster, interview.

${ }^{114}$ Denise, interview.

${ }^{115}$ Many years later Arlene discovered that the RCMP had placed her name on a list of subversives without her knowledge. Perhaps the RCMP used the intelligence they gathered in their drug investigations to supplement their work on subversion. Arlene, interview. On RCMP investigations of homosexuals, see Gary Kinsman and Patrizia Gentile, " "In the Interests of the State": The Anti-gay, Anti-lesbian National Security Campaign in Canada: A Preliminary Research Report," Laurentian University, 1998.

116 Jerry, interview (1992).

${ }^{117}$ Ivy, interview.

${ }^{118}$ Toronto police were not alone in this practice. Author Merril Mushroom reports that in 1950s Miami, lesbians were forced to perform oral sex on police officers. James T. Sears, Lonely Hunters: An Oral History of Lesbian and Gay Southern Life, 1948-1968 (Colorado: Westview Press, 1997), 42-44.

${ }^{119}$ This was a concern for Betty. See Betty, interview by LMH, [Toronto?], 1987.

${ }^{120}$ Lois Stewart, interview.

121 Ibid. The suggestion that the cops would "arrest everyone in the place" contradicts the testimony of other narrators whose descriptions of policing methods are provided above, and in fact moments later she herself states that the police were never around. However, I include Lois' comments here since they illustrate how safe she felt from the threat of police harassment and arrest.

${ }^{122}$ Betty and Sandy, interview by LMH, [Toronto?], 1987; Lois Stewart, interview; Denise, interview.

${ }^{123}$ Lynn was encouraged to assault and steal money from male patrons, but refused. Theft violated her personal moral code, but "I wasn't about to admit the them that I thought it was wrong." Lynn, interview. One of Pratt's informants also described acceptance within the community as contingent upon one's willingness to "support and/or participate in some of their activities." Pratt, "A Study of the Female Homosexual Subculture," 44.

${ }^{124}$ Lois Stewart, interview.

${ }^{125}$ I do not want to suggest that these groups were immutable. Indeed, many women who arrived as an uptowner became a downtowner, and many downtowners left the gay life for the suburbs.

${ }^{126}$ In the late 1950s Betty, Sandy and a gay male friend were chased out of the Continental and down the street by two butch downtowners. Betty and Sandy, interview.

${ }^{127}$ Anon., "What is a Downtown Butch," Two 5 (1965), 11.

${ }^{128}$ On demographic changes among the Chinese in the 1960s, see Thompson, Toronto's Chinatown, 138. 


\section{Chenier}

${ }^{129}$ On lesbian bars in Toronto after 1965 see Ross, "Dance to 'Tie a Yellow Ribbon'." ${ }^{130}$ On lesbian feminism in Toronto, see Becki Ross, The House that Jill Built: A Lesbian Nation in Formation (Toronto: University of Toronto Press, 1995).

${ }^{131}$ Pratt, "A Study of the Female Homosexual Subculture," 48. 